\title{
Agronomic efficiency of polymer-coated triple superphosphate in onion cultivated in contrasting texture soils ${ }^{1}$
}

\author{
Eficiência agronômica do superfosfato triplo com polímeros na cebola cultivada em \\ solos com diferentes texturas
}

\author{
Wantuir Filipe Teixeira Chagas ${ }^{2}$, Douglas Ramos Guelfi ${ }^{3 *}$, Eduardo Bucsan Emrich ${ }^{4}$, André Leite Silva ${ }^{2}$ and \\ Valdemar Faquin ${ }^{3}$
}

\begin{abstract}
Information related to phosphate fertilization and coated phosphate fertilizer in onion is scarce. Thus, this study was carried out to evaluate agronomic efficiency, production and nutritional characteristics of triple superphosphate coated with polymers in onion cultivated in contrasting texture soils. Two experiments were carried out under protected conditions in pots containing $5 \mathrm{~kg}$ soil. The experimental design was completely randomized with treatments arranged in a 2 x 5 factorial: triple superphosphate (TSP) and polymer-coated triple superphosphate (TSP+P) applied in five phosphorus rates: Dystroferric Red Latosol (LVdf) (clayey) $=0 ; 100 ; 200 ; 400 ; 800 \mathrm{mg} \mathrm{P}_{2} \mathrm{O}_{5} \mathrm{~kg}^{-1}$, and Quartzarenic Neosol (sandy) = 0; $75 ; 150 ; 300 ; 600 \mathrm{mg} \mathrm{P}_{2} \mathrm{O}_{5} \mathrm{~kg}^{-1}$, with three replications. Results indicated that polymer-coated TSP showed no difference for bulb mass and agronomic efficiency for phosphorus fertilization. Agronomic efficiency of phosphorus fertilization decreased with the increase in the amount of phosphorus applied. Phosphorus accumulation for onion bulb cultivated in Dystroferric Red Latosol (LVdf) was higher with the use of polymer-coated triple superphosphate. Growth, production and nutritional characteristics in onion were affected by phosphorus. The highest bulbs mass production and phosphorus accumulation occurred at the doses of 783; $629 \mathrm{mg} \mathrm{kg}^{-1} \mathrm{P}_{2} \mathrm{O}_{5}$ (Dystroferric Red Latosol - LVdf), and of 406; $600 \mathrm{mg} \mathrm{kg}^{-1} \mathrm{P}_{2} \mathrm{O}_{5}$ (Quartzarenic Neosol -RQ).
\end{abstract}

Key words: Allium cepa L.. Coated fertilizers. Phosphorus.

RESUMO - Devido à escassez de informações relacionadas à adubação fosfatada para a cebola e às tecnologias de revestimento de fertilizantes fosfatados realizou-se esse estudo para avaliar as características nutricionais, produtivas e a eficiência agronômica do superfosfato triplo revestido com polímeros em cultivos de cebola, em Latossolo Vermelho (argiloso) e Neossolo Quartzarênico (arenoso). Foram conduzidos dois experimentos em casa de vegetação em vasos com capacidade para $5 \mathrm{~kg}$ de solo. $\mathrm{O}$ delineamento experimental foi inteiramente casualizado com os tratamentos distribuídos em arranjo fatorial 2 x 5: superfosfato triplo (SFT) e superfosfato triplo revestido com polímeros (SFT+P) aplicados em cinco doses de fósforo: Latossolo Vermelho = 0; 100; 200; 400; $800 \mathrm{mg} \mathrm{P}_{2} \mathrm{O}_{5} \mathrm{~kg}^{-1}$ e no Neossolo Quartzarênico = 0; 75; 150; 300; $600 \mathrm{mg} \mathrm{P}_{2} \mathrm{O}_{5} \mathrm{~kg}^{-1}$, com três repetições. O revestimento do SFT com polímeros não alterou a massa de bulbos e o índice de eficiência agronômica da adubação fosfatada. A eficiência agronômica da adubação fosfatada diminui com o aumento na quantidade de fósforo aplicada. O acúmulo de fósforo no bulbo da cebola cultivada no Latossolo Vermelho foi maior com a aplicação do superfosfato triplo revestido com polímeros. As características de crescimento, produtivas e a nutrição da cebola foram influenciadas positivamente pelas doses de fósforo. As maiores produções de massa de bulbos e acúmulos de fósforo ocorreram nas doses de 783; $629 \mathrm{mg} \mathrm{kg}^{-1}$ de $\mathrm{P}_{2} \mathrm{O}_{5}$ (Latossolo Vermelho), e de 406; $600 \mathrm{mg} \mathrm{kg}^{-1}$ de $\mathrm{P}_{2} \mathrm{O}_{5}$ (Neossolo Quartzarênico), respectivamente.

Palavras-chave: Allium cepa L.. Fertilizantes revestidos. Fósforo.

\footnotetext{
* Autor para correspondência

DOI: $10.5935 / 1806-6690.20160053$

${ }^{1}$ Recebido para correspondência em 03/12/2014; aprovado em 03/11/2015

Trabalho realizado com financiamento da CAPES, CNPq, FAPEMIG e parte da qualificação de Doutorado do primeiro autor apresentada ao Programa de Pós-Graduação em Ciência do Solo da Universidade Federal de Lavras

${ }^{2}$ Programa de Pós-Graduação em Ciência do Solo, Departamento de Ciência do Solo, Universidade Federal de Lavras, Lavras-MG, Brasil, wantuirfilipe@gmail.com, andreleitefranca@hotmail.com

${ }^{3}$ Departamento de Ciência do Solo, Universidade Federal de Lavras, Lavras-MG, Brasil, douglasguelfi@dcs.ufla.br, vafaquin@dcs.ufla.br

${ }^{4}$ Instituto Federal do Triângulo Mineiro, Campus Ituiutaba, Ituiutaba-MG, Brasil, eduardoemrich@iftm.edu.br
} 


\section{INTRODUCTION}

Regarding the economic aspects, onion is the third most important vegetable crop grown in Brazil, after potatoes and tomatoes (BETTONI, 2013; MENEZES JÚNIOR; GONÇALVES; KURTZ, 2013). Increase in yield and improvements in health and quality of onion bulbs are influenced by adequate phosphorus supply (AGUIAR NETO et al., 2014). P deficiency causes reduction in the root system growth, in the leaf area, in the bulbs mass, in yield, and delays onion maturation (MENDES et al., 2008; RIZK et al., 2012).

In this context, $\mathrm{P}$ has great importance in the management of soil fertility cultivated with vegetables, which in general draw large amounts of this nutrient over the cropping years. This nutrient is also important since the largest part of the Brazilian soils presents high fixation capacity and low P availability (LEITE et al., 2009).

The low utilization of $\mathrm{P}$ from the fertilizer by the plants (between 20-60\% of the applied amount (Chien et al., 2009)) is due to undesired chemical reactions of $\mathrm{P}$ with solid minerals and with cations, such as $\mathrm{Al}^{3+}$ and $\mathrm{Fe}^{2}$, influenced by the soil $\mathrm{pH}$. Thus, the slow- or controlledrelease fertilizer is a possible strategy to act promoting synchronization between the phosphorus absorption curve of the culture and the release of the fertilizer's nutrients for soil solution (DU; ZHOU; SHAVIV, 2006; DAI. et al., 2008; SHI et al., 2009).

Polymer-coated phosphate fertilizers have as a principle the gradual release of nutrients to the soil solution (BANSIWAL et al., 2006; BROSCHAT et al., 2008; FAGERIA et al., 2014; ABAT et al., 2014; DEGRYSE; MCLAUGHLIN, 2014), which is in contrast with the full and immediate release observed in soluble phosphate fertilizers, or the too slow release observed in natural phosphates.

Furthermore, granules coating reduces phosphorus contact with iron and aluminum oxides, decreasing the formation of compounds containing unavailable $\mathrm{P}$ for the plants (GAZOLA et al., 2013).

The understanding of coating performance is of great important for satisfactory results (VASCONCELOS et al., 2010; KAUNISTO et al., 2011; SILVA et al., 2012;). Among the principal mechanisms of coated phosphate fertilizers, it should be mentioned the reduction of the contact between soluble $\mathrm{P}$ with the solid phase of the soil and the reduced precipitation between $\mathrm{P}$ and $\mathrm{Al}^{3+}$ and $\mathrm{Fe}^{2+}$ present in the soil solution which is in direct contact with the fertilizer.

Fulford and Hernandez (2009) found smaller amounts of phosphorus bonded to aluminum and iron when using polymer-coated triple superphosphate, which resulted in the increase of $\mathrm{P}$ availability in the soil.

According to Tindall (2007), the use of coated monoammonium phosphate (MAP) in maize provided $37.2 \%$ fertilizers saving. In cotton, fertilizer saving was $38.9 \%$ due to higher efficiency of the fertilizer and to the reduction of the amount applied.

Due to the lack of information related to phosphorus fertilization for onion and new technologies for coated phosphate fertilizers, this study was carried out to evaluate nutritional, production and agronomic efficiency characteristics of polymer-coated triple superphosphate in onion crops in soils with contrasting texture.

\section{MATERIAL AND METHODS}

The experiments were carried out in a greenhouse at the Department of Soil Science of the Federal University of Lavras, Lavras - MG, from September 2013 to December 2013. It was used two soils classified as Dystroferric Red Latosol (LVdf) and Quartzarenic Neosol (RQ) (EMBRAPA, 2013), collected at 0-20 cm depth. Then, the collected soil was air dried, trimmed, sieved in a four millimeters mesh, homogenized and placed in $5 \mathrm{~kg}$ pots. Concomitantly, soil samples were collected for chemical and textural characterization (Table 1).

Soil $\mathrm{pH}$ was determined in water, in the soil:water ratio of $1: 2.5 ; \mathrm{H}+\mathrm{Al}\left(\mathrm{Ca}(\mathrm{OAc})\right.$ method at $0.5 \mathrm{~mol} \mathrm{~L}^{-1}$ concentration, $\mathrm{pH} 7.0$; exchangeable $\mathrm{Ca}^{2+}, \mathrm{Mg}^{2+}$ and $\mathrm{Al}^{3+}$ were extracted with $\mathrm{KCl} 1 \mathrm{~mol} \mathrm{~L}^{-1}$ and determined by titration; Pand K were extracted by Mehlich-1 and analyzed by colorimetry $(\mathrm{P})$ and flame photometry $(\mathrm{K})$; organic carbon was determined by oxidation with potassium dichromate; $\mathrm{Zn}, \mathrm{Mn}$ and $\mathrm{Cu}$ were extracted by Mehlich-1 and determined by atomic absorption spectrophotometry. Values of effective CEC (t); CEC at pH 7.0 (t); sum of bases (SB), and base saturation percentages (V\%) and aluminum saturation percentages $(\mathrm{m})$ were indirectly obtained by using the values of potential acidity, exchangeable bases, and exchangeable aluminum (CFSEMG, 1999).

It was used a completely randomized design with the treatments distributed in a factorial $2 \times 5$ : triple superphosphate (TSP) and polymer-coated triple superphosphate (TSP+P) applied at five phosphorus doses: Dystroferric Red Latosol (LVdf) = 0; 100; 200; 400; $800 \mathrm{mg} \mathrm{P}_{2} \mathrm{O}_{5} \mathrm{~kg}^{-1}$, and Quartzarenic Neosol

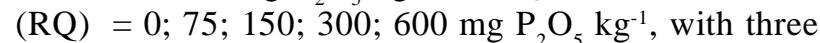
replications. The experimental plot consisted of a $5 \mathrm{~kg}$ pot containing three onion plants. 
Table 1 - Chemical attributes (1) and texture (2) of Dystroferric Red Latosol (LVdf) and Quartzarenic Neosol (RQ) used in onion crops

\begin{tabular}{|c|c|c|}
\hline Chemical atributes and texture & Dystroferric Red Latosol & Quartzarenic Neosol \\
\hline pH in water & 5.5 & 5.5 \\
\hline $\mathrm{Al}^{3+}\left(\mathrm{cmol}_{\mathrm{c}} \mathrm{dm}^{-3}\right)$ & 0.0 & 0.4 \\
\hline $\mathrm{H}+\mathrm{Al}\left(\mathrm{cmol}_{\mathrm{c}} \mathrm{dm}^{-3}\right)$ & 2.1 & 2.3 \\
\hline $\mathrm{Ca}^{2+}\left(\mathrm{cmol}_{\mathrm{c}} \mathrm{dm}^{-3}\right)$ & 0.4 & 0.1 \\
\hline $\mathrm{Mg}^{2+}\left(\mathrm{cmol}_{\mathrm{c}} \mathrm{dm}^{-3}\right)$ & 0.1 & 0.1 \\
\hline $\mathrm{K}^{+}\left(\mathrm{mg} \mathrm{dm}^{-3}\right)$ & 8.0 & 34 \\
\hline Effective CEC $\left(\mathrm{cmol}_{\mathrm{c}} \mathrm{dm}^{-3}\right)$ & 0.5 & 0.7 \\
\hline Potential CEC $\left(\mathrm{cmol}_{\mathrm{c}} \mathrm{dm}^{-3}\right)$ & 2.6 & 2.6 \\
\hline Alumnum saturation (\%) & 0.0 & 60 \\
\hline Base saturation percentage (\%) & 20.0 & 11.0 \\
\hline P- Mehlich-1 (mg dm $\left.{ }^{-3}\right)$ & 0.0 & 0.0 \\
\hline P-remaining $\left(\mathrm{mg} \mathrm{L}^{-1}\right)$ & 2.3 & 20.9 \\
\hline $\mathrm{Cu}\left(\mathrm{mg} \mathrm{dm}^{-3}\right)$ & 2.2 & 0.1 \\
\hline $\mathrm{Zn}\left(\mathrm{mg} \mathrm{dm} \mathrm{m}^{-3}\right)$ & 0.5 & 2.3 \\
\hline $\mathrm{Fe}\left(\mathrm{mg} \mathrm{dm}^{-3}\right)$ & 25.1 & 17.5 \\
\hline $\operatorname{Mn}\left(\mathrm{mg} \mathrm{dm}^{-3}\right)$ & 4.0 & 8.0 \\
\hline Organic matter $\left(\mathrm{g} \mathrm{kg}^{-1}\right)$ & 1.5 & 0.9 \\
\hline Sand $\left(\mathrm{g} \mathrm{kg}^{-1}\right)$ & 19 & 92 \\
\hline Silt $\left(\mathrm{g} \mathrm{kg}^{-1}\right)$ & 14 & 2.0 \\
\hline Clay $\left(\mathrm{g} \mathrm{kg}^{-1}\right)$ & 67 & 6.0 \\
\hline
\end{tabular}

It was carried out liming in order to increase base saturation to 70\% (CFSEMG, 1999), and the limestone used was formed by mixing calcium carbonate and magnesium carbonate (p.a), in a ratio Ca:Mg - 4:1, undergoing a period of 30 days incubation.

Subsequently, basic fertilization was carried out as recommended by Malavolta (1980), with all other nutrients, except $\mathrm{P}$, through pro-analysis salts sources. Macro and micronutrients doses for each pot were $100 \mathrm{mg}$ $\mathrm{N}$; $50 \mathrm{mg} \mathrm{K} ; 40 \mathrm{mg} \mathrm{S} ; 5 \mathrm{mg} \mathrm{Zn} ; 1.5 \mathrm{mg} \mathrm{Cu} ; 3.6 \mathrm{mg} \mathrm{Mn}$; $0.8 \mathrm{mg} \mathrm{B} ; 0.15 \mathrm{mg} \mathrm{Mo} / \mathrm{dm}^{3}$. Maintenance fertilization was carried out with the reagents (P.A) in all the treatments, with $200 \mathrm{mg} \mathrm{dm}^{-3} \mathrm{~N}+130 \mathrm{mg} \mathrm{dm}^{-3} \mathrm{~K}$, using urea and potassium sulfate.

After applying the fertilizers in the pots, it was carried out transplanting of three onion seedlings per plot of the Baia Periforme cultivar, which had previously been produced in polystyrene trays. This cultivar presents the following characteristics: pear-shaped bulb, thin neck, yellow peel and tolerance to long storage periods.

From the limestone incubation to the harvest, soil moisture of the pots was kept constant at 70\% (w/w).
At the beginning of bulbification, leaf samples were collected for the evaluation of the nutrient content. Samples considered the young and fully expanded leaves, as recommended by Mendes et al. (2008).

Bulbs harvest was carried out in the period in which plants presented more than $70 \%$ damping-off (130 days after transplanting). After cure in greenhouse, seven days after harvest, bulbs mass was evaluated.

After the evaluation, bulbs were placed in paper bags and dried at $75{ }^{\circ} \mathrm{C}$ in an oven with forced air circulation until constant weight for subsequent determination of the nutrient content. Shoot dry matter was ground in a Wiley mill, and sampled for nitropercloric digestion, followed by colorimetric phosphorus determination.

Values of $\mathrm{P}$ accumulation were determined by multiplying the dry matter and the $\mathrm{P}$ content in the bulb of onion plants. After obtaining these data, the agronomic efficiency of the phosphate fertilizer was calculated:

Agronomic efficiency $($ EAP $)=$ shoot dry matter with phosphorus fertilization (mg) - shoot dry matter without phosphorus fertilization $(\mathrm{mg}) / \mathrm{P}$ dose $(\mathrm{mg})$; in 
mg of shoot dry matter/mg $\mathrm{P}_{2} \mathrm{O}_{5}$ applied (FAGERIA; SANTOS; MORAES, 2010).

Data were subjected to analysis of variance and regression, using the SISVAR $4.3^{\circledR}$ software (FERREIRA, 2011). Among the linear, quadratic, exponential and logarithmic models, it was chosen the one of most significant regression coefficient at $5 \%$ probability by the $\mathrm{F}$ test.

\section{RESULTS AND DISCUSSION}

\section{Clayey Dystroferric Red Latosol (LVdf)}

Bulbs mass, $\mathrm{P}$ content and agronomic efficiency of phosphorus fertilizer in onion plants were significantly influenced $(\mathrm{p} \leq 0.05)$ only by phosphorus doses. For P content accumulation in the bulbs, there was significance for the isolated effect of doses, sources and for the interaction between these factors (Table 2).

For all $\mathrm{P}_{2} \mathrm{O}_{5}$ doses applied in onion plants, regardless of the TSP form, with or without coating, there was an increase in bulbs mass compared to the control (without $\mathrm{P}$ application). Bulb mass increased up to the dose of $783 \mathrm{mg} \mathrm{dm}^{-3} \mathrm{P}_{2} \mathrm{O}_{5}$ and was equal to $183.9 \mathrm{~g} \mathrm{pot}^{-1}$, which is an increase of $161 \mathrm{~g} \mathrm{pot}^{-1}(702 \%)$, compared to the control (Figure 1a).

According to Mendes et al. (2008), onion plants deficient in phosphorus showed bulbs with reduced size and with decreased yield.

Tekalign et al. (2012) reported that phosphorus fertilization influences onion commercial yield (bulbs mass), and it is of fundamental importance for the production of seed bulbs, since the application of $40 \mathrm{~kg} \mathrm{ha}^{-1} \mathrm{P}$ increased onion sprouting in 53\%, when compared to control treatment.

Phosphorus content in the leaf ranged between 0.93 $\mathrm{g} \mathrm{kg}^{-1}$ in the control treatment to $2.1 \mathrm{~g} \mathrm{~kg}^{-1}$ at a dose of 408 $\mathrm{mg} \mathrm{dm}{ }^{-3} \mathrm{P}_{2} \mathrm{O}_{5}$, which was the highest $\mathrm{P}$ content in onion leaves (Figure 1b). Values of phosphorus content found in this study were below $3.0 \mathrm{~g} \mathrm{~kg}^{-1}$, which is considered ideal by Malavolta (1997) in onion leaves. However, the highest $\mathrm{P}$ content $\left(2.10 \mathrm{~g} \mathrm{~kg}^{-1}\right)$ was found within the optimal range of 2 to $4 \mathrm{~g} \mathrm{~kg}^{-1}$ for onion leaves, according to the Commission of Soil Fertility - RS/SC (2004).

Phosphorus content in the bulb increased with $\mathrm{P}_{2} \mathrm{O}_{5}$ doses applied where TSP $+\mathrm{P}$ had been applied (Figure 1c). The maximum $\mathrm{P}$ content in the bulb was $3.27 \mathrm{~g} \mathrm{~kg}^{-1}$, and it occurred at a dose of $459.1 \mathrm{mg} \mathrm{dm}^{-3}$ $\mathrm{P}_{2} \mathrm{O}_{5}$ with the application of TSP+P, whereas for the uncoated TSP, the highest P content in the bulb occurred at the dose of $459.1 \mathrm{mg} \mathrm{dm}^{-3} \mathrm{P}_{2} \mathrm{O}_{5}$.

The greatest phosphorus accumulation in the bulb (629 mg pot ${ }^{-1} \mathrm{P}$ ) occurred at a dose of $781.43 \mathrm{mg} \mathrm{kg}^{-1} \mathrm{P}_{2} \mathrm{O}_{5}$ using TSP+P. With the application of uncoated TSP, the maximum value of $\mathrm{P}$ accumulation was $294.94 \mathrm{mg} \mathrm{pot}^{-1}$, and it occurred at a dose of $772.28 \mathrm{mg} \mathrm{kg}^{-1} \mathrm{P}_{2} \mathrm{O}_{5}$. Thus, it can be affirmed that $\mathrm{TSP}+\mathrm{P}$ promoted better phosphorus use since it provided maximum accumulation value 53\% higher than the highest value obtained with TSP application.

Agronomic efficiency index in onion cultivation in Clayey Dystroferric Red Latosol (LVdf) decreased with the increase of $\mathrm{P}_{2} \mathrm{O}_{5}$ doses, and was equal to the application of TSP+P and TSP (Figure 1e).

Fageria et al. (2014) evaluated the agronomic efficiency of coated phosphate fertilizers in rice and reported that the applied $\mathrm{P}$ sources were classified according tothe efficientPusein the following descending sequence: polymer-coated simple superphosphate $=$ triple superphosphate $>$ polymer-coated triple superphosphate > polymer-coated ammoniated simple superphosphate > simple superphosphate > MAP > ammoniated simple superphosphate.

\section{Quartzarenic Neosol with sandy texture}

Quartzarenic Neosol in onion cultivation, bulb mass, $\mathrm{P}$ accumulation, $\mathrm{P}$ content in the leaves and in the bulbs, and agronomic efficiency were significantly influenced $(\mathrm{p} \leq 0.05)$ by $\mathrm{P}_{2} \mathrm{O}_{5}$ doses. However, $\mathrm{P}$ content in the bulb and $\mathrm{P}$ accumulation in the bulb were also significantly influenced by the absence or presence of TSP coating (Table 3).

In all $\mathrm{P}_{2} \mathrm{O}_{5}$ doses, regardless of the TSP form, there was an increase in bulbs mass when compared to the control (without $\mathrm{P}$ application ). Bulb mass increased up to a dose of $406 \mathrm{mg} \mathrm{dm}^{-3} \mathrm{P}_{2} \mathrm{O}_{5}$, and was equal $210.2 \mathrm{~g}$ pot $^{-1}$, which is an increase of $189.4 \mathrm{~g} \mathrm{pot}^{-1}(910 \%)$, when compared to the control (Figure 2a).

$\mathrm{P}$ content in the leaves, in the bulbs, and $\mathrm{P}$ accumulation in the bulb of onion plants grown in Quartzarenic Neosol (RQ) increased linearly up to the maximum dose applied (600 mg kg-1 $\mathrm{P}_{2} \mathrm{O}_{5}$ ); (Figure $2 \mathrm{~b}, 2 \mathrm{c}$ and $2 \mathrm{~d}$ ) and the agronomic efficiency index decreased with the increase in $\mathrm{P}$ doses (Figure 2e). For every $100 \mathrm{mg} \mathrm{P}_{2} \mathrm{O}_{5}$ applied in onion plants, there was increase of $0.28 \mathrm{~g} \mathrm{~kg}^{-1}, 0.37 \mathrm{~g} \mathrm{~kg}^{-1}$ and $95.74 \mathrm{mg}$ pot $^{-1}$ in $\mathrm{P}$ content in the leaves, in the bulbs and in $\mathrm{P}$ accumulation, respectively.

Aguiar-Neto et al. (2014) evaluated growth and $\mathrm{P}$ accumulation in different onion cultivars and found 
Table 2 - Results of the F test for bulb mass (BM), phosphorus content in the leaf (PCleaf), phosphorus content in the bulb (PCbulb), phosphorus accumulation in the bulb (PAB), agronomic efficiency index of TSP forms (AEI), and the respective means and coefficients of variation obtained by the analysis of variance for onions cultivation in Clayey Dystroferric Red Latosol (LVdf)

\begin{tabular}{lccccc}
\hline \multirow{2}{*}{ Variation source } & \multicolumn{5}{c}{ Dystroferric Red Latosol (LVdf) } \\
\cline { 2 - 6 } & $\mathrm{BM}$ & PCleaf & PCbulb & PAB & AEI \\
\hline TSP forms & $0.312^{\text {ns }}$ & $0.005^{\text {ns }}$ & $7.27^{*}$ & $15.68^{* *}$ & $0.77^{\text {ns }}$ \\
Doses & $40.76^{* *}$ & $3.010^{*}$ & $4.69^{* *}$ & $27.07^{* *}$ & $18.43^{* *}$ \\
Forms x Doses & $1.111^{\mathrm{ns}}$ & $2.112^{\mathrm{ns}}$ & $4.59^{* *}$ & $5.19^{* *}$ & $0.84^{\mathrm{ns}}$ \\
& $\mathrm{g} \mathrm{pot}^{-1}$ & $\mathrm{~g} \mathrm{~kg}^{-1}$ & $\mathrm{~g} \mathrm{~kg}^{-1}$ & $\mathrm{mg} \mathrm{pot}^{-1}$ & $\mathrm{mg} \mathrm{mg}^{-1}$ \\
Mean & 107.50 & 1.51 & 1.79 & 215.34 & 432.76 \\
CV $(\%)$ & 24.04 & 37.70 & 31.91 & 35.57 & 28.63 \\
\hline
\end{tabular}

$\mathrm{ns}=$ not significant $; * \mathrm{p} \leq 0,05 ; * * \mathrm{p} \leq 0,01$

Figure 1 - Onion bulb mass (a), phosphorus content in the leaf (b), P content in the bulb (c), P accumulation in the bulb (d), and agronomic efficiency (e) in the cultivation of onion in Clayey Dystroferric Red Latosol (LVdf) with

(a)

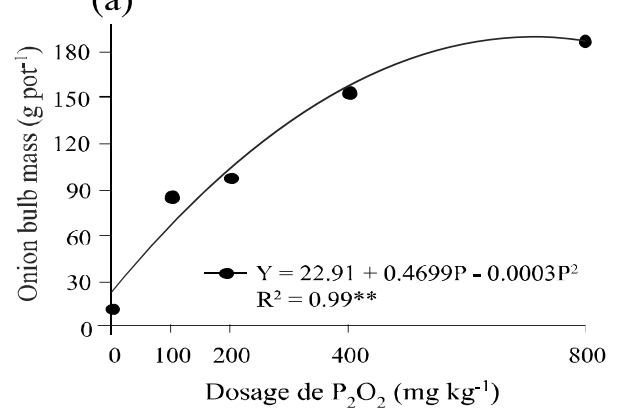

(c)

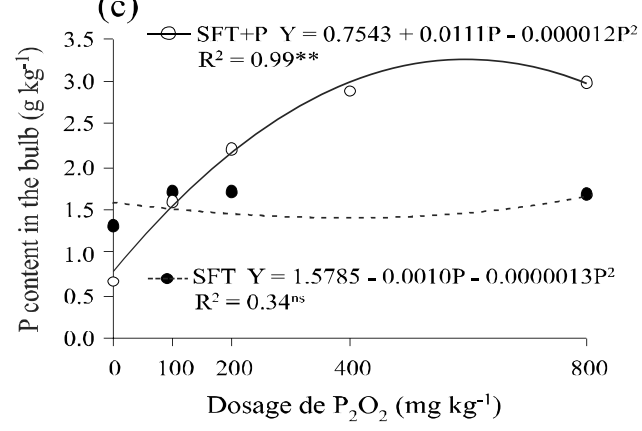

(b)
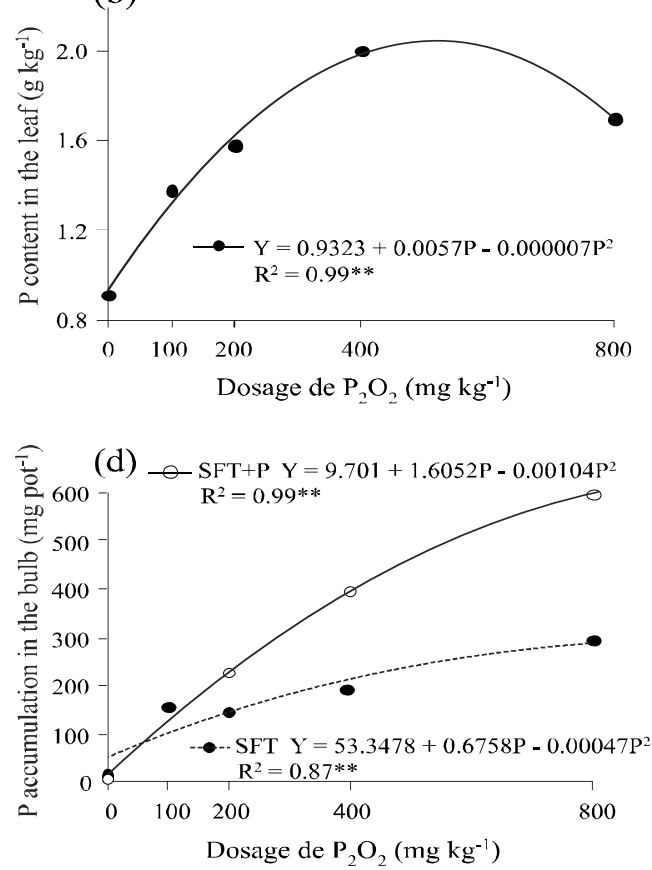

(e)

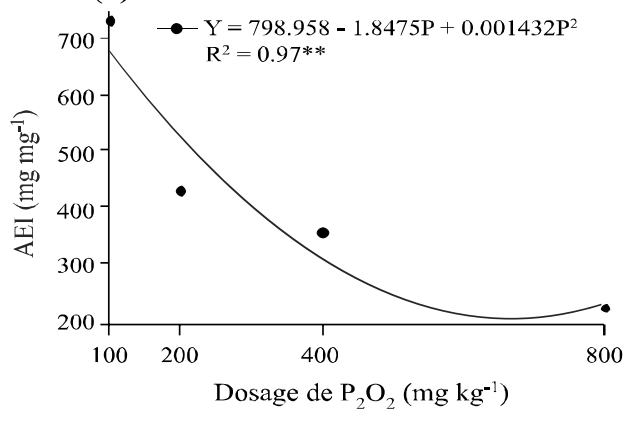

* $5 \%$ significance level $(\mathrm{p} \leq 0.05)$ by the $\mathrm{F}$ test 
Figure 2 - Onion bulbs mass (a), P content in the leaf (b), P content in the bulb (c), P accumulation in the bulb (d), and agronomic efficiency index (e) in onion cultivation in Sandy Quartzarenic Neosol (RQ)
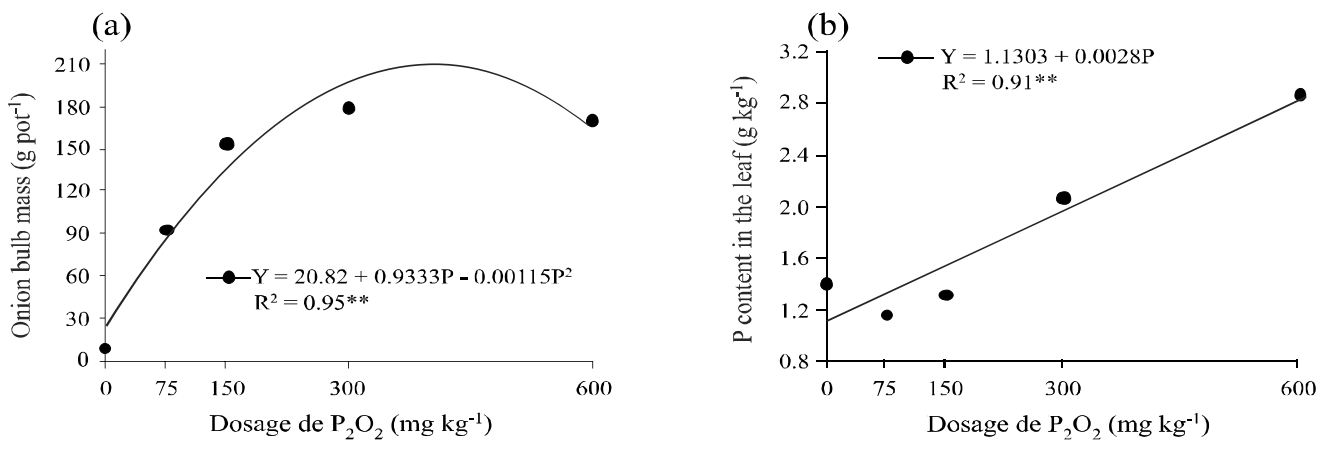

(c)
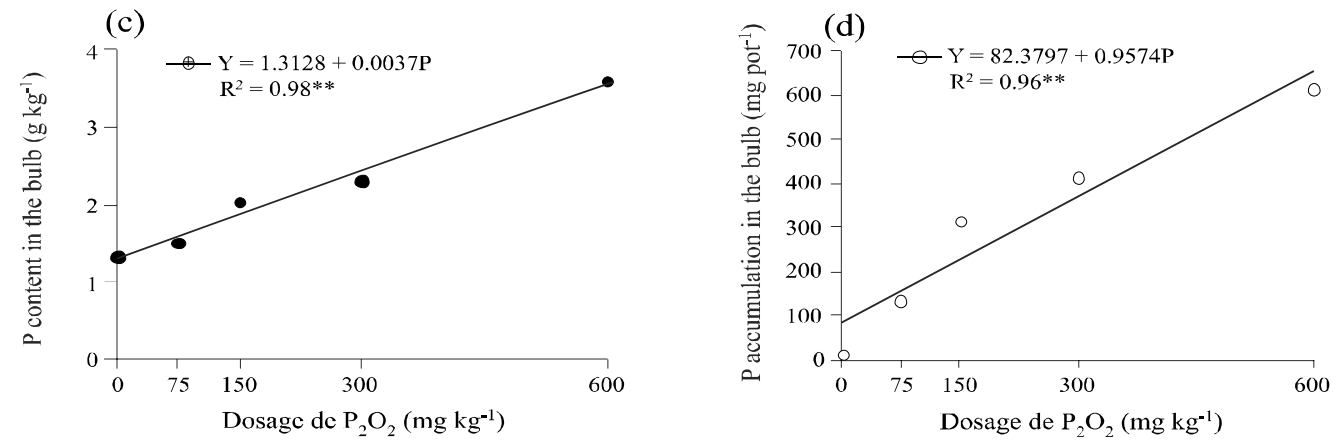

(e)

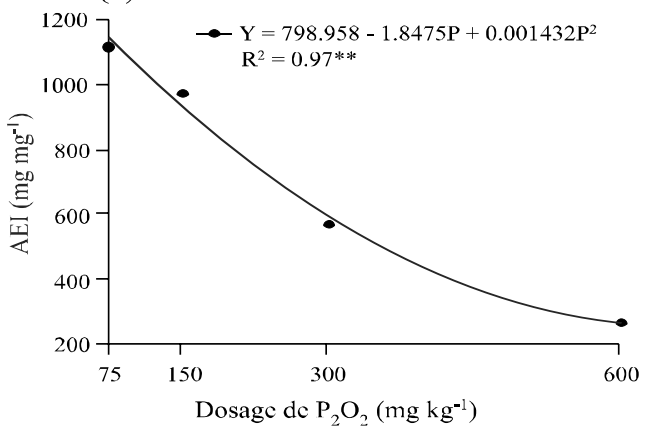

*5\% significance level $(\mathrm{p} \leq 0.05)$ by the $\mathrm{F}$ test

Table 3 - Results of the F test for bulb mass (BM), phosphorus content in the leaf (PCleaf), phosphorus content in the bulb (PCbulb), phosphorus accumulation in the bulb (PAB), agronomic efficiency of TSP forms (AEI), and respective means and coefficients of variation obtained by analysis of variance for onion cultivation in Sandy Quartzarenic Neosol (RQ)

\begin{tabular}{lccccc}
\hline \multirow{2}{*}{ Variation source } & \multicolumn{3}{c}{ Quartzarenic Neosol (RQ) } \\
\cline { 2 - 5 } & $\mathrm{BM}$ & PCleaf & PCbulb & AcP & AEI \\
\hline TSP forms & $0.377^{\mathrm{ns}}$ & $2.185^{\mathrm{ns}}$ & $9.29^{* *}$ & $5.35^{*}$ & $5.37^{\mathrm{ns}}$ \\
Doses & $43.713^{* *}$ & $10.23^{* *}$ & $12.26^{* *}$ & $23.65^{* *}$ & $24.75^{* *}$ \\
Forms x Doses & $1.336^{\mathrm{ns}}$ & $0.93^{\mathrm{ns}}$ & $1.745^{\mathrm{ns}}$ & $1.537^{\mathrm{ns}}$ & $2.84^{\mathrm{ns}}$ \\
Mean & $\mathrm{g} \mathrm{vas0}^{-1}$ & $\mathrm{~g} \mathrm{~kg}^{-1}$ & $\mathrm{~g} \mathrm{~kg}^{-1}$ & $\mathrm{mg} \mathrm{vaso}^{-1}$ & $\mathrm{mg} \mathrm{mg}^{-1}$ \\
& 120.83 & 1.77 & 2.16 & 297.79 & 732.79 \\
CV $(\%)$ & 21.91 & 30.48 & 29.10 & 39.97 & 25.96 \\
\hline
\end{tabular}

$\mathrm{ns}=$ not significant; $* \mathrm{p} \leq 0,05 ; * * \mathrm{p} \leq 0,01$ 
adjustment to the linear model for $\mathrm{P}$ accumulation in the bulb. The authors also reported maximum values of $\mathrm{P}$ accumulation in the bulb of $37.29 \mathrm{mg}$ plant $^{-1}$ in plants cultivated in a Haplic Cambisol with loam sandy texture, located in the municipality of Petrolina. In other crop cultivated in a Eutrophic Red-Yellow Argisol in the municipality of Baraúna, $\mathrm{P}$ accumulation values were $11.30 \mathrm{mg} \mathrm{plant}^{-1}$.

The maximum values of $\mathrm{P}$ content in the leaf $\left(2.90 \mathrm{~g} \mathrm{~kg}^{-1}\right)$ and in the onion bulb (3.60 $\left.\mathrm{g} \mathrm{kg}^{-1}\right)$ occurred at a dose of $600 \mathrm{mg} \mathrm{kg}^{-1} \mathrm{P}_{2} \mathrm{O}_{5}$. These values were $28 \%$ (leaf) and $9 \%$ (bulb) higher compared to the maximum values found in cultivation in Clayey Dystroferric Red Latosol (LVdf) (Figures 1b and 1c). This is due to higher buffering capacity of clayey soils when compared to sandy soils.

The capacity factor of clayey soils is high. Thus, it can only be achieved minor changes in $\mathrm{P}$ content of the soil solution with the application of higher P doses, which may not be economically interesting. This fact occurs due to higher adsorption in clayey soils (MACHADO et al., 2011; NOVAIS et al., 2007).

Machado and Souza (2012) reported that the use of P sources of gradual release makes its availability in the soil increase over time, and the most pronounced effect was observed in the following soil texture sequence: clay $>$ intermediate texture $>$ sandy texture.

For $\mathrm{P}$ accumulation in onion plants cultivated in Quartzarenic Neosol (RQ), there was no significance $(\mathrm{p} \leq 0,05)$ for the interaction between $\mathrm{P}$ and doses forms (Table 3), unlike what occurred in the Clayey Dystroferric Red Latosol (LVdf) (Table 2), where doses higher than $80 \mathrm{mg} \mathrm{dm}^{-3} \mathrm{TSP}+\mathrm{P}$ resulted in higher values of $P$ accumulation in onion plants. Mean value of $\mathrm{P}$ accumulation in the application of TSP+P was $348.08 \mathrm{mg} \mathrm{pot}^{-1}$, and mean values of $\mathrm{P}$ accumulation in the application of TSP was $247.50 \mathrm{mg} \mathrm{pot}^{-1}$, with no significant difference $(\mathrm{p} \leq 0.05)$ between means.

Similarly to the Dystroferric Red Latosol (LVdf), the agronomic efficiency index in onion plants cultivated in Sandy Quartzarenic Neosol (RQ) decreased with the increase in P doses. Values of agronomic efficiency of phosphate fertilizer in Quartzarenic Neosol (RQ) ranged between 1.117.8 and $269.5 \mathrm{mg} \mathrm{mg}^{-1}$ (Figure 3e), and in the Dystroferric Red Latosol (LVdf), variation ranged between 731.7 and $219.0 \mathrm{mg} \mathrm{mg}^{-1}$ (Figure 1e).

Results obtained in onion plants cultivated in Quartzarenic Neosol (RQ) presented no significant differences between TSP forms for the variables quantified and analyzed in this study.

\section{CONCLUSIONS}

1. Polymer-coated TSP did not increase bulbs mass and agronomic efficiency index of the phosphorus fertilization;

2. In both soils, agronomic efficiency of phosphate fertilizer decreased with the increase in the amount of phosphorus applied to the onion plants;

3. Phosphorus accumulation in onion bulbs cultivated in Clayey Dystroferric Red Latosol (LVdf) is higher with the application of polymer-coated triple superphosphate;

4. Regardless of the coated TSP, growth, production and nutritional characteristics in onion increased in function of phosphorus doses;

5. The highest bulbs mass production and phosphorus accumulation in onions cultivated in Dystroferric Red Latosol (LVdf) occurred at the doses of 783; $629 \mathrm{mg}$ $\mathrm{kg}^{-1} \mathrm{P}_{2} \mathrm{O}_{5}$, and in Quartzarenic Neosol (RQ), at doses of 406; $600 \mathrm{mg} \mathrm{kg}^{-1} \mathrm{P}_{2} \mathrm{O}_{5}$, respectively.

\section{REFERENCES}

ABAT et al. Formulation, synthesis and characterization of boron phosphate $\left(\mathrm{BPO}_{4}\right)$ compounds as raw materials to develop slow-release boron fertilizers. Journal of Plant Nutrition and Soil Science, v. 177, n. 6, p. 860-868, 2014.

AGUIAR NETO, P. et al. Crescimento e acúmulo de macronutrientes na cultura da cebola em Baraúna (RN) e Petrolina (PE). Revista Brasileira de Engenharia Agrícola e Ambiental, v.18, n.4, p.370-380, 2014.

ALIYU, U. et al. Correlation and path coefficient analysis for some yield related traits in onion (Allium cepa L.) Journal of Plant Science, v. 2, n. 3, 366-369, 2007.

BANSIWAL, A.K. et al. Surfactant-Modified Zeolite as a Slow Release Fertilizer for Phosphorus. Journal of Agricultural and Food Chemistry, v. 54, n. 13, p. 4773-4779, 2006

BETTONI, M. M. et al. Crescimento e produção de sete cultivares de cebola em sistema orgânico em plantio fora de época. Semina, v. 34, n 5, p. 2139- 2151, 2013.

BROSCHAT, T.K. Release Rates of Soluble and Controlledrelease Boron Fertilizers. HortTechnology, v. 18, n 3, p. 471474, 2008.

CHIEN, SH.; PROCHNOW, L.I.; CANTARELLA, H. Recent developments of fertilizer production and use to increase nutrient efficiency and minimize environmental impacts. Advances in Agronomy, v. 102: 261-316, 2009.

COMISSÃO DE FERTILIDADE DO SOLO DO ESTADO DE MINAS GERAIS - CFSEMG. Recomendações para o uso de corretivos e fertilizantes em Minas Gerais. 5. ed. Viçosa, 1999. 310p. 
COMISSÃO DE QUÍMICA E FERTILIDADE DO SOLO RS/SC. Manual de adubação e calagem para os Estados do Rio Grande do Sul e Santa Catarina. 10. ed. Porto Alegre, 2004. 400p

DAI J.J. et al. Study on the rapid method to predict longevity of controlled release fertilizer coated by water soluble resin. Agricultural Science in China, v. 7, n. 9, p. 1127-1132, 2008.

DEGRYSE, F.; McLAUGHLin, M.J. Phosphorus Diffusion from Fertilizer: Visualization, Chemical Measurements, and Modeling. Soil Science Society of America Journal, v. 78, n. 3, p. 832-842, 2014.

DU, C.; ZHOU, J.; SHAVIV, A. Release Characteristics of Nutrients from Polymer-coated Compound Controlled Release Fertilizers. Journal of Polymers and the Environment, v. 14, n. 3, p.223-230, 2006.

EMPRESA BRASILEIRA DE PESQUISA AGROPECUÁRIA. Sistema Brasileiro de Classificação de Solos. 3. ed. Brasília, 2013. $353 \mathrm{p}$.

FAGERIA, N.K.; SANTOS, A.B.; MORAES, M.F. Yield, potassium uptake, and use efficiency in upland rice genotypes. Communications in Soil Science and Plant Analysis, v. 41, n. 22 , p. 2676-2684, 2010.

FERREIRA. D.F. Sisvar: um sistema computacional de análise estatística. Ciência e Agrotecnologia, v. 35. n. 6. p. 1039-1042. 2011.

FULFORD, A.; J. HERNANDEZ. Impacting phosphate mobility in a lead-contaminated urban 367 soil. In: ACS Annual Meeting abstracts. 2009. Pittsburg, Anais eletrônicos... Pittsburg: A-C-S. 368 2009. <www.acs.confex.coml> Acesso em: 11 abr. 2014.

GAZOLA, R.N. et al. Efeito residual da aplicação de fosfato monoamônio revestido por diferentes polímeros na cultura de milho. Revista Ceres, v. 60, n.6, p. 876-884, 2013.

KAUNISTO, E. et al. Mechanistic modeling of drug release from polymer-coated and swelling and dissolving polymer matrix systems. International Journal of Pharmaceutics, v. 418, n. 1, p. 54-77, 2011.

LEITE, P.B. et al. Níveis críticos de fósforo, para eucalipto, em casa de vegetação, em função da sua localização no solo. Revista Brasileira de Ciência do Solo, v. 33, n. 5, p.13111322, 2009.

MACHADO, V.J. et al. Curvas de disponibilidade de fósforo em solos com diferentes texturas após aplicação de doses crescentes de fosfato monoamônico. Bioscience Journal, v. 27, n. 1, p. 7076, 2011.

MACHADO, V.J.; SOUZA, C.H.E. Disponibilidade de fósforo em solos com diferentes texturas após aplicação de doses crescentes de fosfato monoamônico de liberação lenta. Bioscience Journal, v.28, suplemento 1, p.1-7, 2012.

MALAVOLTA, E. Elementos de nutrição mineral de plantas. Piracicaba: Agronômica Ceres, 1980. 251p.

MALAVOLTA, E.; VITTI, G.C.; OLIVEIRA, S.A. Avaliação do estado nutricional de plantas: Princípios e aplicações. Piracicaba: Potafós, 1997. 308p.

MENDES, A.M.S.; SILVA, D. J.; FARIA, C.M.B.; RESENDE, G.M. ; OLIVEIRA NETO, M.B. ; SILVA, M.S. L. Nutrição Mineral e Adubação da Cultura da Cebola no Submédio do Vale do São Francisco. In: Empresa Brasileira de Pesquisa Agropecuária. Petrolina: Embrapa Semiárido, 2008. p 1-10. (Circular técnica 86).

MENEZES JÚNIOR F.O.G; GONÇALVES P.A.S; KURTZ C. Biomassa e extração de nutrientes da cebola sob adubação orgânica e biofertilizantes. Horticultura Brasileira, v. 31, n. 4, p. $642-648,2013$.

NOVAIS, R. F.; SMYTH, J. T.; NUNES, F. N. Fósforo. In: NOVAIS, R. F.; VENEGAS, V. H. A.; BARROS, N. F.; FONTES, R.L.F,; CANTARUTTI, R. B.; NEVES, J.C.L. (Org.). Fertilidade do Solo. 1 ed. Viçosa: Sociedade Brasileira de Ciência do Solo, 2007, p. 471-550.

RIZK, F.A. et al. Effect of different nitrogen plus phosphorus and sulphur fertilizer levels on Growth, Yield and Quality of Onion (Allium cepa L.). Journal of Applied Sciences Research, v. 8, n. 7, p. 3353-3361, 2012.

SHI Y.L et al. Development and application of slow release fertilizer. Agricultural Science in China, v. 8, n. 6, p. i, 2009.

SILVA A.A. et al. Influência da aplicação de diferentes fontes de MAP revestido com polímeros de liberação gradual na cultura do milho. Bioscience Journal, v. 28, Suplemento 1, 240-250, 2012.

TEKALIGN, T.; ABDISSA, Y.; PANT, L.M. Growth, bulb yield and quality of onion (Allium cepa L.) as influenced by nitrogen and phosphorus fertilization on vertisol. II: Bulb quality and storability. African Journal of Agricultural Research, v. 7, n. 45, p. 5980 -5985, 2012.

TINDALL, T. A. Recent Advances in P Fertilizer Technologies Polymer Coatings and Avail Technology. Simpósio sobre Informações Recentes para Otimização da Produção Agrícola. IPNI. Piracicaba. 2007.

VASCONCELOS, A. C. P.; JUNIOR, A. C. S.; SILVA, A. A.; LANA, R. M Q. Conteúdo de fósforo e nitrogênio na massa seca do milho após aplicação de diferentes fontes de MAP revestidos com polímeros de liberação gradual. In: REUNIÃO BRASILEIRA DE MANEJO E CONSERVAÇÃO DO SOlO E DA ÁGUA, 18., 2010, Teresina. Anais... Teresina: Embrapa Meio-Norte. CD-ROM. 